\title{
Aphanocladium album by via sub-irrigation in the control of Pyrenochaeta lycopersici and Meloidogyne incognita on tomato in a plastic-house
}

\author{
N. SASANELLI ${ }^{1}$, F. CICCARESE ${ }^{2}$, I. PAPAJOVÁ ${ }^{3}$ \\ ${ }^{1}$ Institute for Plant Protection - CNR, Section of Nematology, Via G. Amendola 122/D, 70126 Bari, Italy, E-mail: \\ n.sasanelli@ba.ipp.cnr.it; ${ }^{2}$ Department of Biology and Plant Pathology of the University of Bari, \\ Via G. Amendola 165/A, 70126 Bari, Italy; ${ }^{3}$ Parasitological Institute of Slovak Academy of Sciences, Hlinkova 3, \\ 040 01, Košice, Slovak Republic
}

\begin{abstract}
Summary
Two experiments were carried out to assess the efficacy of different chemicals (azoxystrobin, fosthiazate, methamsodium) and of the chitinolytic fungus Aphanocladium album (isolate MX-95), that could be alternatives to methyl bromide, against the soil borne pathogen Pyrenochaeta lycopersici and the root-knot nematode Meloidogyne incognita on tomato in a plastic house in southern Italy. In the first trial, the treatments were azoxystrobin (1.25 1 a.i. /ha), fosthiazate (1.5 1 a.i. /ha) and biological control agent Aphanocladium album isolate MX-95 (2.5 1/plot at $2 \times 10^{7}$ $\mathrm{CFU} / \mathrm{ml}$; plot surface $96 \mathrm{~m}^{2}$ ). In the second experiment, treatments were metham-sodium (1000 1 c.p./ha) and $A$. album $\left(5 \mathrm{1} / \mathrm{plot}\right.$ at $\left.1 \times 10^{7} \mathrm{CFU} / \mathrm{ml}\right)$. In both trials, chemicals and the fungus were applied by via sub-irrigation. Satisfactory control of the corky root and the root-knot nematode attack and a significant yield increase were obtained by application of azoxystrobin, fosthiazate and metham-sodium. A significant reduction of $M$. incognita soil population density occurred in plots treated with $A$. album. Also, high positive correlations were found between the symptoms caused on tomato roots by $M$. incognita and $P$. lycopersici.
\end{abstract}

Key words: Biological control; corky root; root-knot nematodes; chemical treatments; sub-irrigation

\section{Introduction}

A number of studies on the interaction between phytoparasitic nematodes and other soilborne pathogens, both on vegetables and fruit trees, have been conducted (Abawi \& Chen, 1998; Ciccarese et al., 2001a; Francl \& Wheeler, 1993; Lamberti et al., 2001a). During the last decade, severe corky-root symptoms, caused by Pyrenochaeta lycopersici Schneider et Gerlach, have frequently been found in association with attacks by Meloidogyne spp. (Polizzi et al., 2004), both under field and protected conditions in tomato-growing areas. Generally, control of these and other soilborne pathogens was based on chemical treatments, especially soil fumigations with methyl bromide. However, the use of this product has been banned since the beginning of 2005 in developed countries because of its stratospheric ozone depletion. Therefore, its utilization is limited only for "critical use".

A series of other chemicals, is also available as liquid or granular formulations (fumigants and non fumigants), but many of them could be banned after the revision of the European Community (Reg. EC 414/91) (Basile et al., 2003). Moreover, increased concerns for environment safety and human health are stimulating investigation to find new and alternative control strategies that are environmentally sound and economically convenient.

During the last decade, research on low environmental impact alternatives have received a strong impulse and considered a wide range of options, including agronomic (green manures, amendments, crop rotations) and physic methods (soil solarization and steam), the use of biocidal plants, biological control agents and resistant tomato cultivars (Minuto et al., 1995; Gamliel et al., 2000; Tamietti \& Valentino, 2000; Tjamos et al., 2000; Sasanelli \& Greco, 2000; Vannacci \& Gullino, 2000; Sasanelli et al., 2002; D'Addabbo \& Sasanelli, 2003; Nico et al., 2004; D'Addabbo et al., 2005; Castillo et al., 2006).

Recently a new promising biological control agent Aphanocladium album (Preuss) W. Gams isolate MX-95 that is antagonistic to nematodes, fungi and insects (Biali et al., 1972; Yaniv et al., 1979; Ciccarese et al., 2007) could represent a new possible alternative method control against phytoparasitic nematodes and soilborne pathogens to the use of chemicals, thanks to its intensive chitinolytic activity (Ambrico et al., 2002).

Therefore, two trials were carried out on tomato in pro- 
tected crops to investigate i) the suitability of a new technology to apply different treatments (chemical and biological) at lower environmental impact, and that could be alternative to methyl bromide, and ii) the interaction between the soil-borne pathogen $P$. lycopersici and the root-knot nematode Meloidogyne incognita (Kofoid et White) Chitw.

\section{Materials and Methods}

\section{First trial}

A plastic-house of $2.173 \mathrm{~m}^{2}(41 \times 53 \mathrm{~m})$ at Leverano (province of Lecce, Apulia region, southern Italy), with sandy soil heavily infested by $M$. incognita (9 eggs and juveniles $/ \mathrm{cm}^{3}$ soil) and $P$. lycopersici, of which severe symptoms were evident in the previous tomato crop cycles, was selected. The soil was deeply ploughed, rotavated and subdivided in $96 \mathrm{~m}^{2}$ plots $(8 \times 12 \mathrm{~m})$, spaced $1 \mathrm{~m}$ apart, and distributed according to a randomized block design with four replicates per treatment. A sub-irrigation system (depth $20 \mathrm{~cm}$ ) was performed in each plot by PVC drip lines $(\varnothing 1.6 \mathrm{~cm})$ equipped with water emitters (flow rate 4 1/h) every $30 \mathrm{~cm}$ to allow different treatments (Fig. 1).



Fig. 1. Sub-irrigation system with PVC drip lines $(\varnothing 1.6 \mathrm{~cm})$ equipped with water emitters (flow rate $41 / \mathrm{h}$ ) every $30 \mathrm{~cm}$

Treatments were: a) azoxystrobin (1.25 1 a.i./ha, corresponding to 51 c.p./ha); b) fosthiazate (1.5 1 a.i./ha, corresponding to $101 \mathrm{c.p} . / \mathrm{ha}$ ) and c) Aphanocladium album isolate MX-95 (biological control) (2.5 1/plot of a conidial suspension at $\left.2 \times 10^{7} \mathrm{CFU} / \mathrm{ml}\right)$. Untreated plots served as controls.

In each plot, tomato seedlings (cv. Luisa) were transplanted in 3 coupled rows spaced $1 \mathrm{~m}$ each other and with $0.8 \mathrm{~m}$ between the rows of the same coupled row. Plants were spaced $0.3 \mathrm{~m}$ along the row.

Azoxystrobin was applied at transplanting whereas fosthiazate and A. album were applied 1 and 3 days before transplanting, respectively. The chemicals, as liquid formulation, and the fungus A. album were applied by the subirrigation technique connected to a tank, in which were dissolved the products and in which was inserted an aspiration pump (Fig. 2).

A. album was reared in vitro (Fig. 3). The mycelium was dissolved in sterile water and sown in PDA Petri dishes

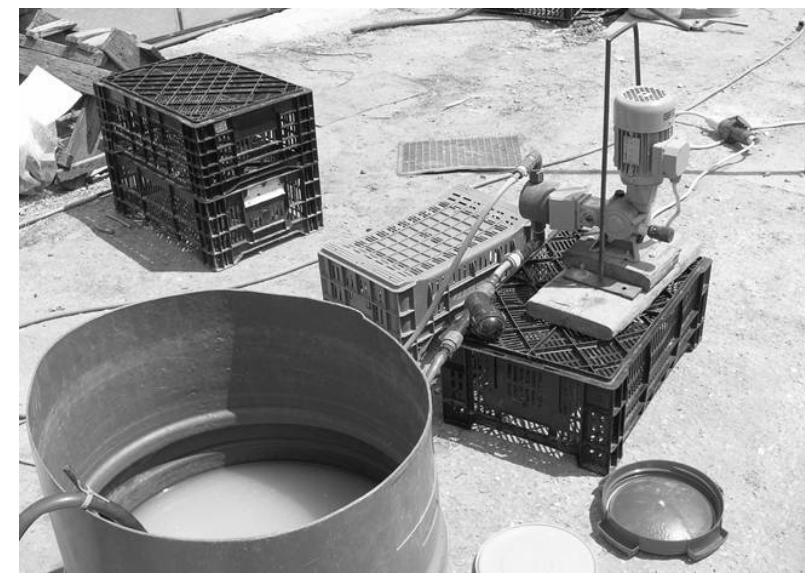

Fig. 2. Distribution system of agro-chemicals and biological control agent by sub-irrigation

incubated in the dark for 7 days at $24{ }^{\circ} \mathrm{C}$. The mycelium was then homogenized in sterile water with a tensioactive to allow the dispersion of strongly hygroscopic conidia. Then, the concentration of the inoculum was determined and diluted to obtain $2 \times 10^{7} \mathrm{CFU} / \mathrm{ml}$ standard conidial suspension. The suspension was then applied by sub-irrigation at a dose of $2.5 \mathrm{l} /$ plot. A filter was set to avoid at the beginning of the sub-irrigation system blocking of the irrigation system.



Fig. 3. Aphanocladium album isolate MX-95

During the growing season the tomatoes received the cultural practices that are common for the area like weed, insect and pathogen control, fertilizer application, irrigation and use of useful pollinators (bumblebees).

Tomatoes were harvested six times from 20 July to 20 October and the total marketable yield of the entire crop cycle calculated. Plants from the central coupled row in each plot were uprooted to estimate the root gall index caused by the nematode attack according to a $0-5$ scale $(0$ no galls and 5 root system completely deformed by large and numerous galls) (Lamberti, 1971). The severity of corky root on main and secondary roots was estimated also according to a $0-5$ scale $(0=$ root healthy; $1=1-10 \%$ affected root surface (a.r.s.); $2=11-25 \%$ a.r.s.; $3=26-50 \%$ a.r.s.; $4=51-75 \%$ a.r.s. and $5=>76 \%$ a.r.s.). Nematodes were extracted from soil samples of each plot processing $500 \mathrm{~cm}^{3}$ soil sub-sample with the Coolen's method (Coolen, 1979).

\section{Second trial}

After one year, the same plastic house was used for a second experiment as above indicated. Plots not treated in 
the previous year were used in this experiment (4.7 eggs and juveniles $/ \mathrm{cm}^{3}$ soil).

The soil was deeply ploughed, rotavated and subdivided in $96 \mathrm{~m}^{2}$ plots $(8 \times 12 \mathrm{~m})$, spaced $1 \mathrm{~m}$ apart, and distributed according to a randomized block design with four replicates per treatment. The sub-irrigation system was performed as previously described.

On the basis of results from the first crop cycle treatments were: a) metham-sodium (470 $\mathrm{Kg}$ a.i./ha) and b) A. album isolate MX-95 (5 1/plot of a conidial suspension at $1 \times 10^{7}$ $\mathrm{CFU} / \mathrm{ml}$ ) applied two times. Untreated plots were used as controls.

Tomato seedlings of cv. Luisa were transplanted in each plot as in the first experiment and during the growing season plants were treated as in the previous year.

Metham-sodium and A. album were applied one month before transplanting. One month after transplanting the A.album treatment was repeated at the same concentration. The fungus was reared and conidial suspension prepared as mentioned in the first experiment. Tomatoes were harvested 6 times from 20 May to 25 July and the total marketable yield calculated.

Plants from the central coupled row in each plot were uprooted to estimate the root gall index and the severity of corky root on main and secondary roots according to the different 0-5 scales previously described. Nematodes were extracted from each plot as in the first trial.

In both trials data were subjected to analysis of variance (ANOVA) and means compared by Duncan's Multiple Range Test.

\section{Results and Discussion}

\section{First trial}

Azoxystrobin was the only treatment that increased significantly tomato marketable yield in comparison to untreated control. No statistical differences were observed in comparison with the other two treatments $(P=0.05)$ (Tab. 1). With this treatment, symptoms and severity of corky root were also significantly reduced either on main and secondary roots $(P=0.01)$.
Table 1. Effect of azoxystrobin, fosthiazate and Aphanocladium album treatments on marketable yield of tomato (cv. Luisa) in a plastic-house infested with Pyrenochaeta lycopersici and Meloidogyne incognita

\begin{tabular}{cccccc}
\hline Treatment & Dose & $\begin{array}{c}\text { Application } \\
\text { time }\end{array}$ & $\begin{array}{c}\text { Marketable } \\
\text { yield } \\
(\mathrm{q} / \mathrm{ha})\end{array}$ \\
\hline $\begin{array}{c}\text { Control } \\
\text { (untreated) }\end{array}$ & 0 & 0 & $436^{*}$ & $\mathrm{a}^{* *}$ & $\mathrm{~A}$ \\
Azoxystrobin & 51 p./ha & $\begin{array}{c}\text { At } \\
\text { transplanting }\end{array}$ & 498 & $\mathrm{~b}$ & $\mathrm{~A}$ \\
Fosthiazate & $101 \mathrm{c.p} . / \mathrm{ha}$ & $\begin{array}{c}1 \text { day before } \\
\text { tranplanting }\end{array}$ & 470 & $\mathrm{ab}$ & $\mathrm{A}$ \\
$\begin{array}{c}\text { Aphanocladium } \\
\text { album } \text { MX-95 }\end{array}$ & $\begin{array}{c}2,51 \\
\left(2 \times 10^{7}\right. \\
\mathrm{CFU} / \mathrm{ml})\end{array}$ & $\begin{array}{c}3 \text { day before } \\
\text { tranplanting }\end{array}$ & 447 & ab & A \\
\hline
\end{tabular}

*Average of four replications; **Data flanked in each column by the same letter are not statistically different according to Duncan's Multiple Range Test (small letters for $P=0.05$; capital letters for $P=0.01$

The nematicide fosthiazate was more effective than azoxystrobin and $A$. album to reduce gall index and final soil $M$. incognita population $(P=0.05)$ (Tab. 2).

The nematode soil population density was also significantly suppressed by $A$. album isolate MX-95 $(P=0.01)$ (Tab. 2), thus suggesting that it is more effective than the antagonistics Streptomyces griseoviridis strain K61 and Trichoderma harzianum strain T-22 tested previously on tomato under protected crop conditions (Filippi et al. 2001; Percoco \& Amenduni, 2001), similar to those of our experiment and with the contemporary presence of $P$. lycopersici and $M$. incognita. However, the root gall index on the tomato roots in plots treated with A. album MX-95 was not reduced. This can be explained by the enzymatic chitinolytic activity of the fungus that reaches its maximum about 3 weeks after the application of the fungus (Ciccarese et al., 2001b; Ambrico et al., 2002).

\section{Second trial}

Metham-sodium significantly increased tomato marketable yield in comparison to untreated control. No statistical difference was observed between A. album treatment and

Table 2. Effect of azoxystrobin, fosthiazate and Aphanocladium album treatments against Pyrenochaeta lycopersici and Meloidogyne incognita on tomato (cv. Luisa) in a protected crop

\begin{tabular}{|c|c|c|c|c|c|c|c|c|c|c|c|c|}
\hline \multirow{4}{*}{$\begin{array}{l}\text { Treatment } \\
\text { Control } \\
\text { (untreated) }\end{array}$} & \multicolumn{6}{|c|}{ P. lycopersici } & \multicolumn{6}{|c|}{ M. incognita } \\
\hline & \multicolumn{6}{|c|}{ Infestation index $(0-5)$} & \multirow{2}{*}{\multicolumn{3}{|c|}{$\begin{array}{l}\text { Gall index } \\
(0-5)\end{array}$}} & \multirow{2}{*}{\multicolumn{3}{|c|}{$\begin{array}{c}\text { Final population } \\
\text { (eggs and } \\
\text { juveniles } / \mathrm{cm}^{3} \\
\text { soil) }\end{array}$}} \\
\hline & \multicolumn{3}{|c|}{ Main root } & \multicolumn{3}{|c|}{ Secondary root } & & & & & & \\
\hline & $1.8 *$ & $a^{* *}$ & A & 2.5 & $\mathrm{a}$ & A & 4.0 & $\mathrm{a}$ & A & 35 & $\mathrm{a}$ & A \\
\hline Azoxystrobin & 1.0 & $\mathrm{~b}$ & $\mathrm{~B}$ & 1.6 & $\mathrm{~b}$ & $\mathrm{~B}$ & 2.9 & $\mathrm{~b}$ & $\mathrm{~B}$ & 25 & $\mathrm{~b}$ & $\mathrm{AB}$ \\
\hline Fosthiazate & 0.6 & $\mathrm{c}$ & $\mathrm{B}$ & 1.4 & $\mathrm{~b}$ & $\mathrm{~B}$ & 0.4 & $\mathrm{c}$ & $\mathrm{C}$ & 5 & $\mathrm{~d}$ & $\mathrm{C}$ \\
\hline $\begin{array}{l}\text { A. album } \\
\text { isolate MX-95 }\end{array}$ & 1.8 & $\mathrm{a}$ & A & 2.4 & $\mathrm{a}$ & A & 3.9 & $\mathrm{a}$ & A & 15 & $\mathrm{c}$ & $\mathrm{BC}$ \\
\hline
\end{tabular}

*Average of four replications; **Data flanked in each column by the same letters are not statistically different according to Duncan's Multiple Range Test (small letters for $P=0.05$; capital letters for $P=0.01$ ) 
the other treatments (metham-sodium and untreated control) $(P=0.01)$ (Tab. 3). Moreover, metham-sodium treatment significantly decreased root gall index and severity of corky root either on main and secondary roots because of its fungicide and nematicide activity due to the development of methylisothiocyanate.

Table 3. Effect of the metham-sodium and Aphanocladium album treatments on marketable yield of tomato (cv. Luisa) in a plastichouse infested with Pyrenochaeta lycopersici and Meloidogyne incognita

\begin{tabular}{|c|c|c|c|c|c|}
\hline Treatment & Dose & $\begin{array}{c}\text { Application } \\
\text { time }\end{array}$ & \multicolumn{3}{|c|}{$\begin{array}{l}\text { Marketable yield } \\
\qquad(\mathrm{q} / \mathrm{ha})\end{array}$} \\
\hline $\begin{array}{l}\text { Control } \\
\text { (untreated) }\end{array}$ & 0 & 0 & $360 *$ & $\mathrm{a}^{* *}$ & A \\
\hline Metham-Na & $\begin{array}{l}10001 \\
\text { c.p./ha }\end{array}$ & $\begin{array}{l}1 \text { month } \\
\text { before } \\
\text { tranplanting }\end{array}$ & 720 & $\mathrm{~b}$ & B \\
\hline $\begin{array}{l}\text { A. album } \\
\text { isolate } \\
\text { MX-95 }\end{array}$ & $\begin{array}{l}51\left(1 \times 10^{7}\right. \\
\mathrm{CFU} / \mathrm{ml})\end{array}$ & $\begin{array}{c}1 \text { month } \\
\text { before and } \\
\text { after } \\
\text { transplanting }\end{array}$ & 490 & $\mathrm{a}$ & $\mathrm{AB}$ \\
\hline
\end{tabular}

*Average of four replications;

**Data flanked in each column by the same letters are not statistically different according to Duncan's Multiple Range Test (small letters for $P=0.05$; capital letters for $P=0.01$ )

The nematode soil population density and the root gall index were also significantly suppressed by $A$. album isolate MX-95 $(P=0.05)$ (Tab. 4), confirmed the results from the first experiment.

The observed reduction of root gall index may be attributed to the number and time of application of the fungus. In fact, in this second experiment A. album was applied two times: one month before transplanting and one month later.
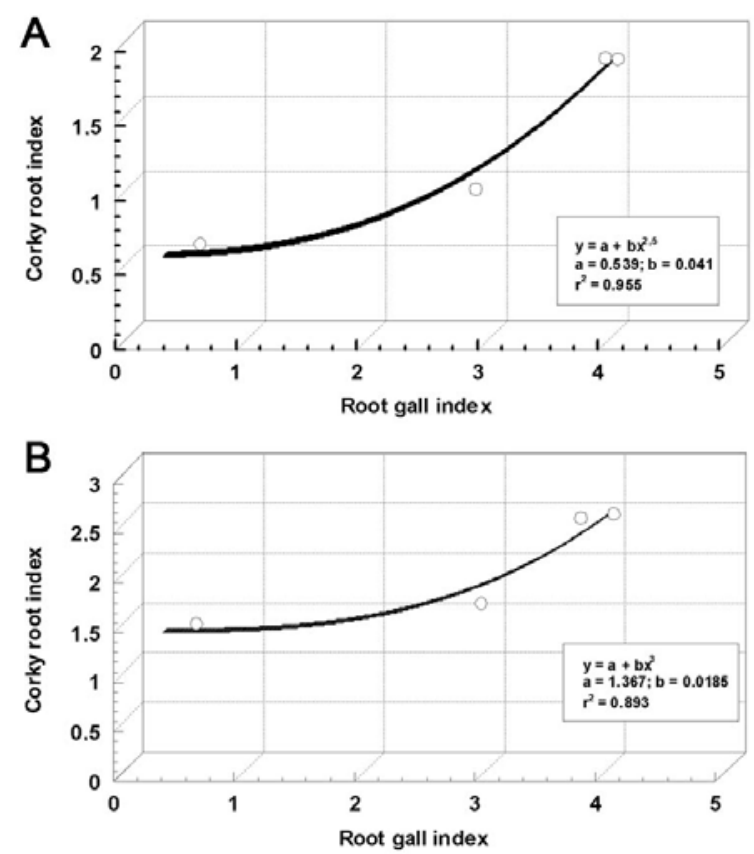

Fig. 4. (I trial) Relationship between gall index, caused by $M$. incognita, and severity of corky root on main tomato roots (A) and on secondary tomato roots (B) caused by P. lycopersici

tions between root gall index and the severity of corky root on main $\left(\mathrm{r}^{2}=0.955\right.$ and 0.975$)$ or secondary $\operatorname{root}\left(\mathrm{r}^{2}=\right.$ 0.893 and 0.851 ) (Figs. 4 and 5). Therefore, it seems that an increase of the nematode attack increases also the severity of $P$. lycopersici. Probably the trophic activity of the second juvenile stage of Meloidogyne on the roots of tomato through the mechanical action of the stylet, that open new wounds, favours penetration and infection of the

Table 4. Effect of the metham-sodium and Aphanocladium album treatments against Pyrenochaeta lycopersici and Meloidogyne incognita on tomato (cv. Luisa) in a protected crop

\begin{tabular}{|c|c|c|c|c|c|c|c|c|c|c|c|c|}
\hline \multirow{3}{*}{ Treatment } & \multicolumn{6}{|c|}{ P. lycopersici } & \multicolumn{6}{|c|}{ M. incognita } \\
\hline & \multicolumn{6}{|c|}{ Infestation index $(0-5)$} & \multirow{2}{*}{\multicolumn{3}{|c|}{$\begin{array}{l}\text { Gall index } \\
(0-5)\end{array}$}} & \multirow{2}{*}{\multicolumn{3}{|c|}{$\begin{array}{l}\text { Final population } \\
\text { (eggs and } \\
\text { juveniles } / \mathrm{cm}^{3} \\
\text { soil) }\end{array}$}} \\
\hline & \multicolumn{3}{|c|}{ Main root } & \multicolumn{3}{|c|}{ Secondary root } & & & & & & \\
\hline $\begin{array}{l}\text { Control } \\
\text { (untreated) }\end{array}$ & $1.7 *$ & $a^{* *}$ & A & 2.8 & $\mathrm{a}$ & $\mathrm{AB}$ & 3.7 & $\mathrm{a}$ & $\mathrm{A}$ & 18 & $\mathrm{a}$ & A \\
\hline Metham-Na & 0.6 & $\mathrm{~b}$ & B & 1.7 & $\mathrm{~b}$ & $\mathrm{~B}$ & 0.5 & $\mathrm{c}$ & $\mathrm{C}$ & 4 & $\mathrm{~b}$ & B \\
\hline $\begin{array}{l}\text { A. album } \\
\text { isolate MX-95 }\end{array}$ & 1.1 & $b$ & B & 3.4 & $\mathrm{a}$ & A & 2.0 & $\mathrm{~b}$ & B & 10 & $\mathrm{~b}$ & $\mathrm{AB}$ \\
\hline
\end{tabular}

*Average of four replications; **Data flanked in each column by the same letters are not statistically different according to Duncan's Multiple Range Test (small letters for $P=0.05$; capital letters for $P=0.01$ )

So in this way the fungus had the possibility to develop its maximum enzymatic chitinolytic activity protecting the seedlings at transplanting from the nematode attack. The second fungus application served as post-transplant protection during the crop cycle. The A. album treatment did not reduce infestation index of $P$. lycopersici on secondary roots, whereas it was effective on main root with a significant reduction of severity of symptoms (Tab. 4).

The experiments revealed significant and positive correla- root tissue by the soil born pathogen $P$. lycopersici (OEPP/EPPO, 2004). This mechanism would explain why the severity of corky root on the tomato roots was not suppressed by A. album during the first trial.

Therefore, the low values of gall index observed on the tomato roots in azoxystrobin, fosthiazate and methamsodium treated plots would explain the lower severity of symptoms of corky root in the same plots. Infestation indexes of $P$. lycopersici were significantly higher on the 

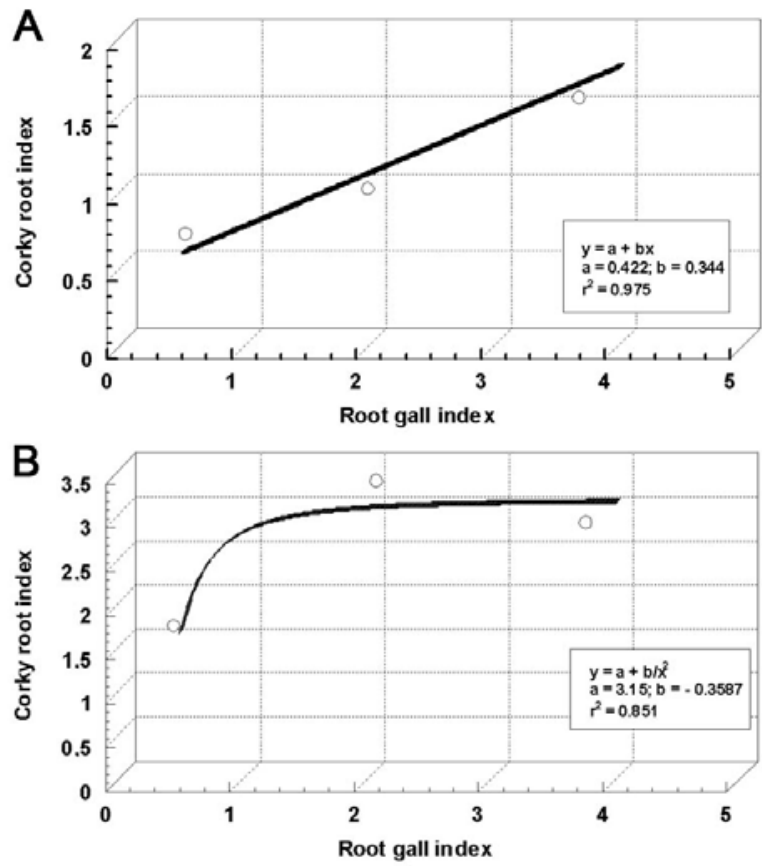

Fig. 5. (II. trial) Relationship between gall index, caused by $M$. incognita, and severity of corky root on main tomato roots (A) and on secondary tomato roots (B) caused by P. lycopersici

roots treated with azoxystrobin (chemical with fungicide activity) than that of roots treated with fosthiazate (chemical with nematicide activity). This is explained by the more opened ways to the penetration of the pathogen fungus that the azoxystrobin is unable to contain because it has not nematicidal activity (Tab. 2). In fact, the fosthiazate and the metham-sodium carring out an intense nematicidal activity are able to protect the root systems from $M$. incognita juvenile attacks giving consequently less possibilities of penetration and infection of $P$. lycopersici.

\section{Conclusions}

Azoxystrobin, fosthiazate and metham-sodium should be recommended for the control of simultaneous attacks of $P$. lycopersici and $M$. incognita. For these chemicals and also for biological products application through the sub-irrigation technique would results more beneficial than with any other methods of aplication. In fact, in this way it is possible to reduce production costs because of the repeated use of the irrigation system in several cultural practices (irrigation, fertilization, and crop protection).

Among crop protection methods with low enviromental impact, soil solarization is positively considered to control both soil borne pathogen and root-knot nematodes but its use is not always possible and convenient (Aloj et al., 1998; Lamberti et al., 2001b). Soil solarization requires covering the soil for a long time (1-2 months) with costly plastic materials, can be performed only in warm areas and for high value crops (Garibaldi \& Gullino, 1991). Application of A. album isolate MX-95 has no enviromental impact and therefore could be considered routinely for the control of these soil borne pathogens and nematodes if it is applied more than 1 time and at least 1 month before transplanting. However, more investigations are suggested to ascertain the most appropriate rates and timing of application.

\section{Aknowledegement}

The research was undertaken within the framework of a bilateral project between the National Council of Research (CNR-Italy) and the Slovak Academy of Science (SAVSlovak Republic). Project No 3/CNR 3 (2007-2009).

\section{References}

ABAwI, G. S., CHEN, J. (1998): Concomitant pathogen and pest interactions. In: BARKer, K. R., Pederson, G. A., Whidam, G. L. (Eds) Plant and Nematode Interactions. Monograph number 36. Madison, Wisconsin, U.S.A.: American Society of Agronomy, pp. $135-158$

AloJ, B., D'ERrico, F. P., BIANCO, M. (1998): Efficacy of soil solarization in the control of soil parasites. Notiziario sulla protezione delle piante, 8: 159 - 164 (In Italian)

Ambrico, A., Ceci, G., Garuccio, I., Ciccarese, F. (2002): Chitinolytic activity of isolates of Aphanocladium album. Atti $97^{\circ}$ Convegno Nazionale della Società Botanica Italiana. Lecce, 24 - 27 settembre: 43 (In Italian) Basile, M., D’AdDabBo, T., SASAnelli, N., Basile, A. C. (2003): Fumigants and systemic nematicides in nursery. Italus Hortus, 10 (Supp. 4): 294 - 296 (In Italian)

Biali, M., Dinoor, A., Eshed, N., KenNeth, R. (1972): Aphanocladium album, a fungus inducing teliospore production in rusts. Ann. App. Biol., 72: $37-42$

Castillo, P., Nico A.I., Azcon-Aguilar, C., Del Rio Rincon, C., Calvet, C., Jimenez-Diaz, R. M. (2006): Protection of olive planting stocks against parasitism of root-knot nematodes by arbuscular mycorrhizal fungi. Plant Pathology, 55(5): 705 - 713

Ciccarese, F., D’ADDABbo, T., SAsAnelli, N., Ambrico, A., SChiavone, D., LAMBERTI, F. (2001a): The relationship between Meloidogyne incognita and Verticillim dahliae on eggplant. In Congress Proceedings of the $11^{\text {th }}$ Congress of the Mediterranean Phytopathological Union and of the $3^{\text {rd }}$ Congress of the Sociedade Portuguesa de Fitopatologia. Evora (Portugal), 17-20 September: 342 344

Ciccarese, F., Ambrico, A., Ceci, G. (2001b): Preliminary investigation on the chitinolytic activity of isolates of Aphanocladium album. Atti "VI Convegno Nazionale Biodiversità”. 6-7 settembre, Valenzano, Bari: 1405 - 1409 (In Italian)

Ciccarese, C., Sasanelli, N., Gallo, M., Ziadi, T., LONGO, O. (2007): Biological control of Fusarium-wilt and nematodes on carosello. Incontri Fitoiatrici, Torino 27-02 - 03-03: 64 - 65 (In Italian)

CoOLEN, W.A. (1979): Methods for the extraction of Meloidogyne spp. and other nematodes from roots and soil. In: LAMBERTI F., TAYLOR C. E. (Eds) Root-knot nematodes 
(Meloidogyne species), Systematics, Biology and Control. London, UK: Academic Press, pp. 317 - 329

D'ADDABBO, T., SASANELLI, N. (2003): Control of phytoparasitic nematodes by biocidal plants. Atti XXXV Convegno $S I A, \mathrm{~N}^{\circ} 23$; Napoli, 16-18 settembre: 363 - 364 (In Italian)

D’addabbo, T., Sasanelli, N., Greco, N., Stea, V., BRANDONISIO, A. (2005): Effect of Water, Soil Temperatures, and Exposure Times on the Survival of the Sugar Beet Cyst Nematode: Heterodera schachtii. Phytopathology, 95 (4): 339 - 344

FilipPi, C., Russo, A., Bagnoli, G., Bedini, S, Nuti, M.P. (2001): Activation of composted organic substrates by antagonistic bacteria of phytopathogen agents. Atti Progetto POM B-10 "Sviluppo semi-industriale di matrici organiche da sanse di oliva pre-condizionate con microrganismi antagonisti di patogeni radicali di piante ortive": 35 - 42 (In Italian)

FRANCL, L. J., WHEELER, T. A. (1993): Interaction of plant parasitic nematodes with wilt including fungi. In: KHAN M. W. (Ed) Nematode interactions. London, UK: Chapman \& Hall, pp. $79-103$

Gamliel, A., Austerweil, M., Kritzman, G. (2000): Non-chemical approach to soilborne pest managementorganic amendments. Crop Protection, 19: 847 - 853

GARIBAldi, A., Gullino, L. (1991): Soil solarization in southern European countries, with enphasis on soilborne disease control of protected crops. In: KATAN, J., DE VAY, J. E. (Eds.) Soil solarization. CRC Press Boca Raton, FL, USA: $227-235$

LAMBERTI, F. (1971): Results of nematicidal control on levantin tobacco in the province of Lecce. Il Tabacco, 738: 5 - 10 (In Italian)

Lamberti, F., Ciccarese, F., Sasanelli N., Ambrico, A., D'ADDABBo T., Schiavone, D. (2001a): Relationships between plant parasitic nematodes and Verticillium dahliae on olive. Nematol. mediterr., 29: 3 - 9

Lamberti, F., SAsanelli, N., D’AdDabbo, T., Carella, A. (2001b): Combination of soil solarization and chemical treatments for the control of root-knot nematodes in southern Italy. In Annual International Research Conference on Methyl Bromide Alternatives and Emissions Reductions. November 5 - 9, San Diego, California (U.S.A.)
Minuto, G., Minuto, A., Garibaldi, A., Gullino, M. L. (1995): Soil disinfestation by the combined use of dazomet and soil solarization. Colture Protette, 24: 95 - 101

Nico, A. I., JimÉnez-DìAz, R. M., CAstillo, P. (2004): Control of root-knot by composted agro-industrial wastes in potting mixtures. Crop Protection, 23: $581-587$

OEPP/EPPO (2004): Good plant protection practice. Solanaceous crops under protected cultivation. PP 2/29(1). Bulletin OEPP/EPPO, Bulletin 34: 65 - 77

Percoco, A., AMENDUNi, M. (2001): Biological control of corky root on tomato by composted olive pomace activated with biocontrol agents. Atti Progetto POM B-10 "Sviluppo semi-industriale di matrici organiche da sanse di oliva precondizionate con microrganismi antagonisti di patogeni radicali di piante ortive": $105-107$

Polizzi, G., Cascone, G., D’emilio, A., Castello, I. (2004): Physic and biological methods for the control of Pyrenochaeta lycopersici and Meloidogyne spp. on tomato in a plastic-house. Colture Protette, 33: 81 - 87 (In Italian) SASANELli, N., GRECO, N. (2000): Formulation of a model to relate nematode populations with exposure times to a range of temperatures. Acta Horticulturae, 532: $131-135$ Sasanelli, N., D’addabBo, T., Convertini, G., Ferri, D. (2002): Soil Phytoparasitic Nematodes Suppression and Changes of Chemical Properties Determined by Waste Residues from Olive Oil Extraction. In Proceedings of $12^{\text {th }}$ ISCO Conference, May 26-31, Beijing China. Vol. III: 588 $-592$

TAmietti, G., VAlentino, G. (2000): Effectiveness of soil solarization against soil borne plant pathogens and weeds in Piedmont (Northern Italy). Acta Horticulturae, 532: 151 $-156$

Tuamos, E. C., Polymnia, P. A., Tuamos, S. E. (2000): Implementation of soil solarization in Greece: Conclusions and suggestions. Crop Protection, 19: 843 - 846

VAnNACCI, G., Gullino, M. L. (2000): Use of biological agents against soil borne pathogens: Results and limitations. Acta Horticulturae, 532: $79-87$

YANIV, Z., KenNeTH, R.G., MiURA, J. (1979): Teliospore formation in Puccinia graminis f. sp. tritici grown in axenic culture, induced by the fungus Aphanocladium album. Physiological Plant Pathology, 14: 153 - 156 